\title{
PEMBELAJARAN KIMIA MENGGUNAKAN METODE LEARNING CYCLE 7E DAN GUIDED INQUIRY DITINJAU DARI KEMAMPUAN BERPIKIR KRITIS DAN KREATIVITAS SISWA
}

\author{
Sri Rusmiati ${ }^{1}$, Ashadi $^{2}$, Sulistyo Saputro ${ }^{3}$ \\ ${ }^{1}$ Program Studi Pendidikan Sains Program Pascasarjana \\ Universitas Sebelas Maret Surakarta, 57126, Indonesia \\ sri_och@yahoo.co.id \\ ${ }^{2}$ Program Studi Pendidikan Sains Program Pascasarjana \\ Universitas Sebelas Maret, 57126, Indonesia \\ ashadi_uns@yahoo.com \\ ${ }^{3}$ Program Studi Pendidikan Sains Program Pascasarjana \\ Universitas Sebelas Maret, 57126, Indonesia \\ sulistyo68@yahoo.com
}

\begin{abstract}
ABSTRAK
Pembelajaran learning cycle $7 E$ (LC $7 E$ ) dan guided inquiry adalah pembelajaran berparadigma konstruktivisme yang berpusat pada siswa. Pembelajaran $L C 7 E$ merupakan rangkaian tahap-tahap pembelajaran yang melibatkan keaktifan siswa. Sedangkan guided inquiry memberi kesempatan pada siswa mengumpulkan dan verifikasi data melalui eksperimen, mengolah data dan menganalisis proses inkuiri. Penelitian ini bertujuan untuk mengetahui pengaruh pembelajaran $L C 7 E$, guided inquiry, kemampuan berpikir kritis, kreativitas, dan interaksinya terhadap prestasi belajar. Penelitian ini dilaksanakan bulan Mei 2012-Juli 2013. Populasi penelitian ini adalah siswa kelas X SMA N 1 Magetan tahun Pelajaran 2012/2013. Sampel diperoleh dengan teknik cluster random sampling yang terdiri dari 2 kelas yaitu kelas X-2 yang diberi pembelajaran $L C 7 E$ dan kelas X-1 diberi pembelajaran guided inquiry. Data dikumpulkan dengan metode tes untuk prestasi belajar kognitif, kemampuan berpikir kritis dan kreativitas, angket untuk prestasi belajar afektif dan lembar observasi untuk psikomotor

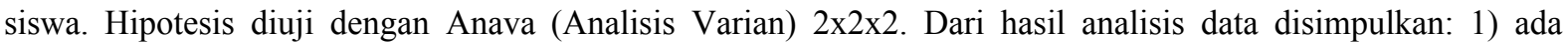
pengaruh pembelajaran $L C 7 E$ dan guided inquiry terhadap prestasi belajar kognitif tetapi tidak pada afektif dan psikomotor, 2) tidak ada pengaruh kemampuan berpikir kritis terhadap prestasi belajar kognitif tetapi ada pengaruh terhadap afektif dan psikomotor, 3) tidak ada pengaruh kreativitas siswa terhadap prestasi belajar kognitif dan afektif tetapi ada pengaruh terhadap psikomotor, 4) tidak ada interaksi antara pembelajaran $L C 7 E$ dan guided inquiry dengan kemampuan berpikir kritis terhadap prestasi belajar kognitif, afektif, dan psikomotor, 5) tidak ada interaksi antara pembelajaran $L C 7 E$ dan guided inquiry dengan kreativitas siswa terhadap prestasi belajar kognitif, afektif, dan psikomotor, 6) ada interaksi antara kemampuan berpikir kritis dan kreativitas siswa terhadap prestasi belajar kognitif dan psikomotor tapi tidak pada afektif, 7) tidak ada interaksi antara pembelajaran $L C 7 E$ dan guided inquiry, kemampuan berpikir kritis, kreativitas terhadap prestasi belajar kognitif, afektif, dan psikomotor siswa.
\end{abstract}

Kata Kunci: learning cycle $7 E$, guided inquiry, kemampuan berpikir kritis, kreativitas siswa, prestasi belajar.

\section{Pendahuluan}

Pendidikan pada dasarnya adalah suatu upaya untuk memberikan pengetahuan, wawasan, keterampilan dan keahlian tertentu kepada manusia untuk mengembangkan bakat serta kepribadian mereka, agar mampu menghadapi setiap perubahan yang terjadi akibat adanya kemajuan Ilmu Pengetahuan dan Teknologi (IPTEK). Oleh karena itu pendidikan merupakan ujung tombak dalam mempersiapkan Sumber Daya Manusia (SDM) yang handal, tangguh, mampu berpikir kritis, bertindak secara logis dan inovatif serta kreatif dalam menghadapi dan menyelesaikan setiap masalah yang kelak akan dihadapinya. Pendidikan yang berkualitas dapat dilakukan dalam kegiatan proses pembelajaran di sekolah. Pada proses 
pembelajaran siswa dapat memperoleh pengalaman yang bermakna bagi kehidupannya.

Siswa berbeda dalam berbagai hal, salah satunyaadalahkemampuanberpikirdanbertindaky angdisebutkemampuaninteligensidanspiritual.

Keseluruhan kemampuan individu untuk berpikir dan bertindak secara terarah dalammengolah dan menguasai lingkungan secara efektif itulah yang perlu diperhatikan dalam proses pembelajaran.

Era globalisasi identik dengan pesatnya Ilmu Pengetahuan dan Teknologi(IPTEK) yang mampu menghantarkan era keterbukaan yang penuh dengan peluang dan tantangan.Siswa perlu dibekali landasan karakter moral yang kuat agar nilai-nilai jati diri sebagai suatu bangsa tidak luntur karena arus globalisasi. Hal ini dapat dilakukan dengan

mengubahtingkahlakusiswamenjadi

manusiadewasayangmampuhidupmandirisebagai anggotamasyarakat dalamlingkunganalamsekitar melalui pendidikan.

Ada 3 aspek penting dalam pelaksanaan pembelajaran yang saling terkait dan tidak dapat dipisahkan, yaitu teaching of thinking, teaching for thinking dan teaching about thinking harus terus ditumbuh-kembangkan (Ausubel. D.P, Novak dan Helen Hanesian, 1978). Pembelajaran ini menekankan pada pengalaman berpikir dan bertindak agar siswa mempunyai tingkah laku sebagai seorang ilmuwan. Pembelajaran learning cycle dan guided inquiry dengan memperhatikan kemampuan berpikir kritis dan kreativitas siswa dimungkinkan dapat menumbuh-kembangkan ketiga aspek tersebut.

Menurut Permendiknas No 26 Tahun 2006 pembelajaran IPA diarahkan untuk mencari tahu dan berbuat sesuatu sehingga dapat membantu siswa untuk memperoleh pemahaman yang lebih mendalam tentang alam sekitar. Salah satu cabang IPA adalah kimia. Olehkarenanyakimiamempunyaikarakteristiksam adenganIPA. Karakteristik tersebut berkaitan dengan obyek ilmu kimia, cara memperoleh, serta peranannya.

Kimia adalah ilmu yang mencari jawaban atas pertanyaan apa, mengapa, dan bagaimana gejala-gejala alam yang berkaitan dengan komposisi, struktur dan sifat, perubahan materi dan energi yang menyertai perubahan materi. Oleh sebab itu, mata pelajaran kimia di SMA melibatkan keterampilan dan penalaran siswa. Ada dua hal yang berkaitan dengan kimia yaitu kimia sebagai produk (pengetahuan kimia yang berupa fakta, konsep, prinsip, hukum dan teori) yang merupakan temuan ilmuwan dan kimia sebagai proses (kerja ilmiah). Oleh sebab itu, pembelajaran kimia dan penilaian prestasi belajar kimia harus memperhatikan karakteristik ilmu kimia sebagai proses dan produk.

Tujuan pembelajaran kimia di SMA berdasarkan kurikulum 2006 antara lain adalah agar peserta didik: memperoleh pengalaman dalam menerapkan metode ilmiah melalui percobaan atau eksperimen, memahami konsep, prinsip, hukum, teori kimia yang saling terkait dan penerapannya dalam menyelesaikan masalah kehidupan sehari-hari dan teknologi. Pencapaian tujuan pembelajaran tersebut mengacu pada standar yang telah ditetapkan oleh pemerintah melalui Permendiknas No 23 Tahun 2006. Lulusan SMA/MA/SMALB/Paket C mampu membangun dan menerapkan informasi dan pengetahuan secara logis, kritis, kreatif dan inovatif dalam pengambilan keputusan (BSNP, 2006).

Pembelajaran ilmu kimia sampai saat ini masih merupakan tantangan terbesar bagi para guru. Hal ini disebabkan karena kimia dianggap sebagai mata pelajaran yang sulit, siswa sering mengalami kesulitan dalam memahami konsepkonsep, istilah-istilah dalam kimia, dan juga kesulitan dalam menggunakan alat-alat kimia di laboratorium. Pembelajaran kimia pada umumnya lebih banyak menekankan pada aspekaspek pengetahuan dan pemahaman sedangkan aspek aplikasi, analisis, evaluasi dan sintesis belum mendapat penekanan yang maksimal. Akibatnya, siswa kesulitan dalam mengaplikasikan konsep- konsep yang telah dipelajari. Siswa juga kurang diberi kesempatan untuk mengembangkan kemampuan berpikir, memahami konsep, dan mengaplikasikan konsep dalam kehidupan nyata. Artinya pembelajaran hanya berpusat pada guru tanpa melibatkan keaktifan siswa.

Akibat lain dari permasalahan diatas kurangnya motivasi siswa terhadap pelajaran kimia karena merasa apa yang sudah dipelajarinya kurang bermanfaat. Dari observasi yang dilakukan di sekolah, guru pada umumnya dalam menyampaikan materi kimia masih monoton, isi mata pelajaran kimia dianggap hafalan, sehingga siswa hanya memahami konsep-konsep yang bersifat abstrak. Oleh 
karena itu perlu dilaksanakan pembelajaran yang melibatkan siswa dalam proses pembelajaran.

Materi pokok larutan elektrolit dan non elektrolit merupakan materi yang diberikan pada siswa klas $\mathrm{X}$ semester genap. Karakteristik materi pokok larutan elektrolit dan non elektrolit antara lain:1)mengandung konsep konkrit, abstrak dan terdefinisikan, 2)mengandung konsep yang akan digunakan sebagai prasyarat pengetahuan pada materi yang lain, 3)mengandung konsep yang sudah pernah dipelajari yang digunakan sebagai pengetahuan awal siswa sebelum mempelajari materi larutan elektrolit dan non elektrolit, 4)pengetahuan materi larutan elektrolit dan non elektrolit banyak berperan dalam kehidupan seharihari.Berdasarkan karakteristik materi larutan elektrolit dan non elektrolit memerlukan kemampuan berpikir kritis dan kreativitas siswa.

Salah satu usaha yang dapat dilakukan oleh guru menumbuh-kembangkan kemampuan berpikir kritis dan kreativitas siswa dengan pembelajaran yang berpusat pada siswa(studentcentered). Pembelajaran yang berpusat pada siswa dapat dilakukan dengan pembelajaran yang berorientasi konstruktivisme. Pada pembelajaran konstruktivismeguru banyak bertanya dan memberi kesempatan kepada siswa untuk mendemonstrasikan pengetahuan yang dimiliki. Pertanyaan-pertanyaan yang disusun oleh guru sedikit mungkin menuntut siswa menghafal. Guru berperan sebagai fasilitator belajar dan siswa sebagai pebelajar yang aktif.

Pendidikanyang berkualitas sangat diperlukan dalam era modern.Peran guru untuk memperhatikan kemampuan yang dimiliki siswa diharapkan dapat mengatasipermasalahanini. Kemampuan berpikirkritis dan kreativitas merupakan contoh faktor internal yang dimiliki siswa. Kemampuan berpikir kritis diterapkan siswa untuk belajar memecahkanmasalah secarasistematis,danmendesainsolusiyangmendas ar. Kreativitas merupakan kemampuan yang sangat berarti dalam kehidupan.

Menurut John Dewey cit Alec Fischer (2009) sekolahadalahtempatmengajarkananak untuk berpikir. Berpikirmerupakan segala aktivitas mental dalam usaha memecahkan masalah,membuatkeputusan,memaknaisesuatu,p encarianjawabandalam mendapatkan suatu makna.Berpikir kritis adalah aktivitas terampil yang dapat dilakukan dengan lebih baik atau sebaliknya, sehingga berpikir kritis menuntut interpretasi dan evaluasi terhadap observasi, komunikasi, dan sumber-sumber informasi lainnya. Selain itu dituntut keterampilan dalam memikirkan asumsi-asumsi, mengajukan pertanyaan-pertanyaan yang relevan, menarik implikasi-implikasi yang dilakukan secara terus menerus.

Kreativitasbukansekedarkeberuntungan, $\mathrm{kr}$ eativitas hanya dapat dilahirkan dari orang yang cerdas yang memiliki kondisi psikologis sehat (Supriyadi, 1994). Kreativitas merupakan salah satu faktor yang dapat menentukan prestasi belajar siswa. Menurut UtamiMunandar(2006)menerangkanbahwakreati vitasmerupakan suatu prosesataukemampuanyangmencerminkankelanc aran,keluwesan,

danorisinalitasdalamberpikir,sertakemampuanunt ukmengelaborasi yaitu mengembangkan,memperkaya,memperinci suatugagasan.

Berdasarkan uraian diatas maka akan dilakukan penelitian untuk mengetahui pengaruh metode learning cycle $7 E$ dan metode guided inquiry terhadap prestasi belajar pada materi larutan elektrolit dan non elektrolit dengan memperhatikan kemampuan berpikir kritis dan kreativitas siswa. Penelitian ini dilakukan di SMA Negeri 1 Magetan pada kelas X Semester genap Tahun Pelajaran 2012/2013.

\section{Metode Penelitian}

Penelitian ini dilaksanakan di kelas $\mathrm{X}$ semester genap SMANegeri 1 Magetan Jalan Monginsidi nomor 24 Magetan tahun pelajaran 2012/2013. Penelitian dilaksanakan pada bulan Mei 2012-Juli 2013. Jenis penelitian yang digunakan adalah penelitian eksperimen semu dengan dua kelompok eksperimen. Kelompok eksperimenpertamadiberikan perlakuan pembelajaranlearning cycle $7 E$ dan kelompok kedua dengan pembelajaranguided inquiry. Populasi penelitian adalah siswa kelas X SMA Negeri 1 Magetan tahun pelajaran 2012/2013 yang terdiri dari 9 kelas. Penelitian ini mengambil 2 kelas eksperimen dengan menggunakan teknik cluster random sampling.

Variabel bebas pada penelitian ini adalahmetode learning cycle $7 E$ dan guided inquiry. Variabel moderator terdiri dari kemampuan berpikir kritis dan kreativitas siswa. Variabel terikat adalah prestasi belajar kimia pada materi larutan elektrolit dan non elektrolit. Prestasi belajar dalam penelitian ini meliputi prestasi belajar kognitif, afektif, dan psikomotor. 
Cara memperoleh data dilakukan dengan menggunakan teknik tes, teknik angket, dan teknik observasi. Adapun teknik tes digunakan untuk pengumpulan data penilaian prestasi belajar kognitif, kemampuan berpikir kritis, dan kreativitas siswa. Teknik angket digunakan untuk pengambilan nilai prestasi belajar afektif. Teknik observasi digunakan untuk penilaian prestasi belajar psikomotor, yang dilakukan oleh 2 guru kimia yang bertindak sebagai observer.

Instrumen penelitian adalah alat atau fasilitas yang digunakan peneliti dalam mengumpulkan data. Berdasarkan variabelvariabel penelitian instrumen terdiri dari instrumen pelaksanaan pembelajaran dan pengumpulan data. Instrumen pelaksanaan pembelajaran terdiri dari: Silabus, Rencana Pelaksanaan Pembelajaran (RPP), dan Lembar Kerja Siswa (LKS). Instrumen pengumpulan data meliputi: tes prestasi belajar kognitif, angket prestasi belajar afektif, lembar observasi psikomotor, dan instrumen pendukung yang terdiri dari tes kemampuan berpikir kritis dan tes kreativitas verbal.

Validitas instrumen yang digunakan dalam penelitian terdiri dari validitas isi dan konstruk. Validitas isi dilakukan dengan menggunakan formula Gregory dengan dua panelis sebagai pakar. Validitas konstruk dilakukan dengan mengujicobakan instrumen untuk mengetahui validitas, reliabilitas, indeks kesukaran dan daya pembeda. Hasil uji coba instrumen yang berupa angket prestasi belajar afektif diukur validitas dan reliabilitasnya. Sedangkan instrumen berupa tes selain uji validitas dan reliabilitas juga akan diukur nilai indeks kesukaran dan daya pembedanya.

Dalam menganalisis data digunakan analisis varian (anava) tiga jalan $2 \times 2 \times 2$. Namun terlebih dahulu dilakukan uji persyaratan analisis yaitu uji normalitas dan uji homogenitas. Uji normalitas bertujuan untuk mengetahui apakah sampel berasal dari populasi yang berdistribusi normal atau tidak. Uji normalitas pada penelitian ini menggunakan metode Lilliefors dengan SPSS 18. Homogenitas untuk mengetahui varians dari sejumlah populasi sama atau tidak dengan menggunakan Levene's Test melalui program SPSS 18. Sebagai tindak lanjut dari analisis varian tiga jalan digunakan Uji Compare Means independent $t$ sample pada variabel yang berinteraksi.

\section{Hasil Penelitian dan Pembahasan}

Data yang diperoleh dalam penelitian ini adalah nilai kemampuan berpikir kritis (KBK), kreativitas (KRV), dan nilai prestasi belajar siswa pada materi larutan elektrolit dan non elektrolit. Prestasi belajar siswa meliputi prestasi belajar kognitif, afektif, dan psikomotor. Deskripsi data prestasi belajar kognitif, afektif, dan psikomotor kelas $L C 7 E$ dan guided inquiry (GInq) disajikan pada Tabel 1.

Tabel 1. Data Prestasi Belajar

\begin{tabular}{lllclll}
\hline Metode & KBK & KRV & $\begin{array}{l}\text { Jum } \\
\text { lah }\end{array}$ & $\begin{array}{l}\text { Kog } \\
\text { nitif }\end{array}$ & Afektif & $\begin{array}{l}\text { Psiko } \\
\text { motor }\end{array}$ \\
\hline LC $7 E$ & Tinggi & Tinggi & 13 & 74,46 & 84,71 & 90,15 \\
& & Rendah & 6 & 78,00 & 86,77 & 80,50 \\
& \multirow{2}{*}{ Rendah } & Tinggi & 7 & 76,00 & 80,98 & 81,71 \\
& & Rendah & 8 & 81,00 & 79,92 & 80,87 \\
\hline GInq & \multirow{2}{*}{ Tinggi } & Tinggi & 11 & 78,54 & 86,70 & 89,00 \\
& & Rendah & 6 & 65,33 & 86,46 & 79,50 \\
& \multirow{2}{*}{ Rendah } & Tinggi & 6 & 70,66 & 87,60 & 83,66 \\
& & Rendah & 11 & 75,63 & 82,27 & 80,18 \\
\hline
\end{tabular}

Pada Tabel 1 diatas nilai prestasi belajar kognitif tertinggi diperoleh siswa dengan kemampuan berpikir kritis rendah, kreativitas rendah $(81,00)$ pada pembelajaran learning cycle $7 E(L C 7 E)$, sedangkan nilai terendah diperoleh siswa dengan kemampuan berpikir kritis tinggi, kreativitas rendah $(65,33)$ pada pembelajaran guided inquiry. Prestasi belajar afektif tertinggi diperoleh siswa dengan kemampuan berpikir kritis rendah, kreativitas tinggi $(87,60)$ pada pembelajaran guided inquiry, sedangkan terendah diperoleh siswa dengan kemampuan berpikir kritis rendah, kreativitas rendah $(79,92)$ pada pembelajaran learning cycle $7 E$. Adapun prestasi belajar psikomotor tertinggi diperoleh siswa dengan kemampuan berpikir kritis tinggi, kreativitas tinggi $(90,15)$ pada pembelajaran learning cycle $7 E$ dan terendah pada siswa dengan kemampuan berpikir kritis tinggi, kreativitas rendah $(79,50)$ pada pembelajaran guided inquiry.

Sebelum dilakukan uji hipotesis, maka dilakukan uji prasyarat yaitu uji normalitas dan homogenitas. Hasil uji normalitas dan homogenitas pada prestasi belajar kognitif, afektif dan psikomotor semua data berdistribusi normal dan homogen. Karena semua data berdistribusi normal dan homogen maka dilakukan uji statistik parametris. Hasil uji hipotesis terhadap prestasi belajar kognitif, afektif dan psikomotor dengan menggunakan software SPSS 18 disajikan dalam Tabel 2 dibawah ini. 
Tabel 2. Uji Hipotesis terhadap Prestasi Belajar

\begin{tabular}{lcccc}
\hline No & Variabel & \multicolumn{3}{c}{ Nilai Signifikan } \\
\hline & & Kognitif & Afektif & Psikomotor \\
& & & & \\
\hline 1 & Metode & 0.028 & 0.087 & 0.843 \\
2 & KBK & 0.877 & 0.025 & 0.006 \\
3 & KRV & 0.749 & 0.461 & 0.000 \\
4 & Met*KBK & 0.824 & 0.230 & 0.450 \\
5 & Met*KRV & 0.338 & 0.276 & 0.581 \\
6 & KBK*KRV & 0.030 & 0.189 & 0.002 \\
7 & Met*KBK*KRV & 0.285 & 0.805 & 0.535 \\
\hline
\end{tabular}

Dari analisis data pada Tabel 2 diatas pelaksanaan pembelajaran kimia menggunakan metode learning cycle (7E)dan guided inquiry ditinjau dari kemampuan berpikir kritis dan kreativitas siswa pada materi larutan elektrolit dan non elektrolit siswa kelas X SMA Negeri 1 Magetan Tahun Pelajaran 2012/2013 memberikan hasil sebagai berikut :

1. Ada pengaruh pembelajaran learning cycle $7 E$ (LC7E) dan guided inquiry terhadap prestasi belajar kognitif tetapi tidak ada pengaruh terhadap

prestasibelajarafektifdanpsikomotor.Pembelajara $\mathrm{n} L C 7 E$ padamaterilarutanelektrolitdannonelektroli takanmenghasilkannilairerataprestasibelajarkogni tifsebesar

78,82

lebihtinggidibandingdenganpembelajaranmenggu nakanmetodeguidedinquiryyangmemperolehnilai reratasebesar73,88.

Kegiatan pembelajaran pada materi larutan elektrolit dan non elektrolit siswa melakukan pengamatan menggunakan alat uji elektrolit untuk membedakan apakah suatu larutan bersifat elektrolit dan non elektrolit. Dari pengamatan gejala-gejala yang ditimbulkan, siswa dapat membuat kesimpulan pengertian larutan elektrolit dan non elektrolit. Larutan-larutan yang diuji dengan menggunakan alat penguji elektrolit dapat diambil dari laboratorium sekolah maupun larutan yang ada dalam kehidupan sehari hari, misalnya air aki, air jeruk, air sabun.Pada akhirnya siswa dapat menerapkan pengetahuan tentang larutan elektrolit dan non elektrolit dalam kehidupan nyata. Winkel (1996)mengemukakan bahwa "Belajar adalah aktivitas mental atau psikis yang berlangsung dalam interaksi aktif dengan lingkungan yang menghasilkan perubahan-perubahan dalam pengetahuan, pemahaman, keterampilan dan nilai sikap. Perubahan itu bersifat secara relatif dan berbekas.Hal ini dapat dijelaskan sebagai berikut.

Pertama,pembelajaran $L C \quad 7 E$ berlangsung melalui fase-fase, setiap fase mewadahi siswa untuk aktif membangun konsep-konsepnya sendiri dengan cara berinteraksi dengan lingkungan fisik maupun sosial. Dengan demikian proses pembelajaran tidak lagi sekedar transfer pengetahuan dari guru ke siswa tetapi perolehan konsep berorientasi pada keterlibatan siswa secara aktif pada proses pembelajaran. Hal ini sesuai teori belajar Piaget (1971) yang mengemukakan pengetahuan dibangun dalam pikiran seseorang dengan kegiatan asimilasi dan akomodasi sesuai dengan skematayangdimilikinya.

Tujuandaripembelajaranlearning cycle7E $(L C$

$7 E)$ menekankanpentingnyapeningkatanpengetahu andanpengembangankonsepyangdihubungkanden gankehidupansehari-hari. Tujuan diatas tidak terlepas dari keunggulannya yang merangsang siswa untuk mengingat kembali materi pembelajaran yang telah mereka dapatkan sebelumnya (fase elicit), memberi motivasi (fase engage), melatih siswa untuk belajar menemukan konsep melalui kegiatan eksperimen (fase explore), melatih siswa menyampaikan secara lisan konsep yang sudah dipelajari (fase explain), memberi kesempatan siswa untuk berpikir, mencari dan menemukan serta menjelaskan contoh penerapan konsep terlaksana pada fase elaborate, evaluate dan extend. Hasil penelitian ini sejalan dengan penelitian yang telah dilakukan oleh Sutee Sornsakda, Paitol Suksringarm, Adisak Singseewo (2009) yang menjelaskan bahwa pembelajaran menggunakan metode siklus belajar (learning cycle) memberikan efek lebih besar pada prestasi akademik.

Pada kegiatan pembelajaran guided inquiry guru memberikan petunjuk atau bimbingan pada siswa agar mampu menemukan sendiri arah dan tindakan-tindakan yang harus dilakukan untuk memecahkan masalah. Pemecahan masalah dapat dilakukan sendiri atau kelompok. Bimbingan dikurangi sedikit demi sedikit seiring dengan bertambahnya pengalaman siswa. Tahap yang digunakan dalam pembelajaran guided inquiry adalah penyajian masalah, pengumpulan dan verifikasi data, eksperimen, perumusan dan pengolahan data dan tahap analisis proses inkuiri (Eggen dan Kauchak cit Trianto, 2007). Hal ini sesuai dengan teori belajar kognitif yang mengacu pada teori belajar konstruktivisme, bahwa siswa harusmenemukansendiri,

mentransformasikaninformasidanmengecekinfor masibarudenganinformasilamasertamerevisinyaji kaaturan-aturanitutidaksesuailagi. Agar benarbenar memahami dan dapat menerapkan 
pengetahuan, siswa harus bekerja memecahkan masalah dan menemukan segala sesuatu untuk dirinya serta berusaha menemukan ide-idenya. Pembelajaran denganguided inquiry memerlukan perubahan kebiasan cara belajar dari menerima informasi dari guru menjadi belajar mandiri atau kelompok.

Kedua, kegiatan pembelajaran $L C 7 E$ dilakukan melalui tahapan yang paling sederhana yaitu guru harus mendatangkan pengetahuan awal siswa agar timbul rasa penasaran (fase elicit), menyampaikan ide atau pengalaman yang sekaligus memberikan motivasi pada siswa agar lebih berminat untuk mempelajari materi yang akan dipelajarinya (fase engage), menyelidiki/ melakukan percobaan (fase explore), ajakan untuk menjelaskan konsep dan definisi awal yang mereka dapatkan pada fase sebelumnya (fase explain), penilaian untuk mengetahui tingkat pengetahuan dan kemampuan (fase evaluate) dan menjelaskan penerapan konsep/memperluas (fase extend).

Hal ini sesuai dengan teori belajar Bruner tentang "Kurikulum Spiral" yang menuntut guru untuk memberi pelajaran setahap demi setahap dari yang sederhana sampai yang kompleks, dimana materi yang sebelumnya sudah diberikan suatu saat muncul secara terintegrasi di dalam suatu materi yang lebih kompleks sehingga siswa akan memperoleh pengetahuan yang utuh. Bruner juga mengemukakan jika anak aktif dan terlibat dalam kegiatan memperoleh konsep maka akan lebih memahami, hal inilah yang merupakan keunggulan dari pembelajaran $L C$ $7 E$. Sedang pada pembelajaran guided inquiry diperlukan perubahan kebiasaan cara belajar yang menerima informasi dari guru apa adanya menjadi belajar mandiri atau kelompok.

2. Tidak ada pengaruh kemampuan berpikir kritis terhadap prestasi belajar kognitif tetapi ada pengaruh terhadap afektif dan psikomotor. Hal ini dapat dijelaskan bahwa berpikir kritis meliputi dua aspek yaitu karakter (disposition) dan keterampilan (ability) (Ennis, 1987). Aspek disposisi meliputi beberapa indikator, sedangkan aspek keterampilan atau kemampuan berpikir kritis meliputi indikator seperti: memberi penjelasan sederhana, membangun keterampilan dasar, menyimpulkan, memberi penjelasan lebih lanjut dan mengatur strategi/taktik.

Kemampuan berpikir kritis tidak bisa muncul dengan sendirinya dan bukan kemampuan yang dibawa sejak lahir, tetapi merupakan kemampuan yang dibentuk oleh pengalaman masa lalu (Asch cit Mukhsin, 2012).
Hal ini dikemukan pula oleh O'Driscoll cit Mukhsin(2012) bahwa kemampuan berpikir kritis berkembang sepanjang waktu dan menjadi semakin jelas dan halus melalui gesekan-gesekan pengalaman yang semakin kuat sebagai hasil kontak seseorang dengan benda atau situasi yang mempengaruhi pola pikirannya, dan pada gilirannya sikapnyapun akan berubah.

Siswa dengan kemampuan berpikir kritis tinggi dan rendah memperoleh nilai prestasi belajar kognitif yang tidak berbeda secara signifikan. Kemampuan berpikir kritis tinggi dan rendah memberikan pengaruh terhadap prestasi belajar afektif dan psikomotornya. Dari perolehan nilai prestasi belajar afektif, siswa dengan kemampuan berpikir kritis tinggi akan memperoleh nilai afektif yang lebih tinggi dibanding siswa dengan kemampuan berpikir kritis rendah.

Siswa dengan kemampuan berpikir kritis tinggi memperoleh nilai psikomotor lebih rendah dibanding siswa dengan kemampuan berpikir kritis rendah yangmemperoleh nilai psikomotor lebih tinggi.

3. Tidak ada pengaruh kreativitas terhadap prestasi belajar kognitif dan afektif tetapi ada pengaruh terhadap prestasi belajar psikomotor. Kreativitas salah satu faktor internal yang dimiliki oleh siswa sangat berpengaruh terhadap prestasi belajar. Kreativitas mempunyai ciri-ciri rasa ingin tahu, keterbukaan terhadap pengalaman dan pengetahuan, toleransi terhadap resiko yang merupakan kesanggupan seseorang untuk mengambil resiko dan energi yang meliputi energi fisik dan mental. Keterbukaan terhadap pengalaman dan pengetahuan berupa kelincahan berpikir dari segala arah, memiliki energi terkait dengan tidak menyerah dalam melakukan sesuatu (Ayan cit J. Candra, 1994).

Selo Soemarjan (1983) menjelaskan bahwa setiap orang memiliki potensi kreatif dalam derajat yang berbeda-beda dandalambidangyangberbeda-beda. Potensi ini perlu dipupuk sejak dini agar dapat diwujudkan. Untuk itu diperlukan kekuatan pendorong, baik dari luar/lingkungan maupun dari dalam individu sendiri. Perlu diciptakan kondisi lingkungan yang dapat memupuk daya kreatif individu maupun dalam masyarakat. Timbul dan tumbuhnya kreatif seseorang individu tidak luput dari pengaruh kebudayaan serta pengaruh masyarakat tempat individu itu hidup dan berkembang. Tetapi tidak cukup itu saja, akhirnya semua kembali pada bagaimana individu itu sendiri, sejauhmana ia merasakan 
kebutuhan dan dorongan untuk melibatkan dalam kegiatan kreatif yang mungkin memerlukan waktu lama. Hal ini menyangkut motivasi internal.

4. Tidak ada interaksi antara pembelajaran learning cycle $7 E$ dan guidedinquiry dengan kemampuan berpikir kritis terhadap prestasi belajar kognitif, afektif, dan psikomotor siswa.Data penelitian pada pembelajaran $L C$ 7 Eprestasi belajar kognitif, afektif, dan psikomotor pada siswa dengan kemampuan berpikir kritis tinggi lebih tinggi dibanding siswa dengan kemampuan berpikir kritis rendah. Hal ini dikarenakan pada pembelajaran $L C 7 E$ dimulai dari tahap yang sederhana menuju tahap yang lebih komplek, sehingga siswa dengan kemampuan berpikir kritis tinggi lebih mudah menyesuaikan.

Pada kelas guided inquiry siswa dengan kemampuan berpikir kritis tinggi memperoleh nilai prestasi kognitif dan afektif yang lebih rendah dibanding siswa dengan kemampuan berpikir kritis rendah. Tetapi prestasi belajar psikomotor siswa dengan kemampuan berpikir kritis tinggi lebih tinggi dibanding siswa dengan kemampuan berpikir kritis rendah. Hal inidimungkinkan karena pembelajaran berlangsung secara kelompok dengan bimbingan guru sehingga siswa dengan kemampuan berpikir kritis rendah lebih mudah menyesuaikan karena ada kerjasama antar siswa dalam kelompok.

5. Tidak ada interaksi antara pembelajaran learning cycle $7 E$ dan guidedinquiry dengan kreativitas terhadap prestasi belajar kognitif, afektif, dan psikomotor siswa. Siswa dengan kreativitas tinggi pada kelas $L C 7 E$ memperoleh prestasi belajar kognitif, afektif, dan psikomotor yang lebih tinggi dibanding siswa dengan kreativitas rendah. Pada pembelajaran guided inquiry siswa dengan kreativitas tinggi memperoleh nilai prestasi belajar kognitif dan afektif yang lebih rendah daripada siswa dengan kreativitas rendah. Tetapi pada prestasi belajar psikomotor sebaliknya.

Hal ini dapat dijelaskan bahwa kedua pembelajaran berparadigma konstruktivisme, dimungkinkan ada faktor internal lain yang tidak dapat dikendalikan. Kalaupun menghasilkan nilai yang berbeda semata-mata disebabkan karena proses pembelajaran dilakukan secara kelompok. Pengaturan kelompok tidak didasarkan kategori kreativitas tinggi dan rendah yang dimiliki oleh siswa.

6. Ada interaksi antara kemampuan berpikir kritis dan kreativitas siswa terhadap prestasi belajar kognitif maupun psikomotor tetapi tidak ada interaksi pada prestasi belajar afektif. Pada ranah kognitif interaksi terjadi pada siswa dengan kemampuan berpikir kritis tinggi kreativitas rendah dan siswa dengan kemampuan berpikir kritis tinggi kreativitas rendah, siswa dengan kemampuan berpikir kritis tinggi kreativitas rendah dan siswa dengan kemampuan berpikir kritis tinggi kreativitas tinggi.

Sedangkan pada ranah psikomotor interaksi terjadi pada siswa dengan kemampuan berpikir kritis rendah kreativitas rendah dan kemampuan berpikir kritis tinggi kreativitas tinggi, siswa dengan kemampuan berpikir kritis rendah kreativitas tinggi dan siswa dengan kemampuan berpikir kritis tinggi kreativitas tinggi, siswa dengan kemampuan berpikir kritis tinggi kreativitas rendah dan siswa dengan kemampuan berpikir kritis tinggi kreativitas tinggi. Interaksi ini terjadi karena kreativitas merupakan suatu proses berpikir, sedangkan kemampuan berpikir memerlukan kreativitas (Guilford cit utami Munandar, 2009:10).

7. Tidak ada interaksi antara pembelajaran learning cycle $7 E$ dan guidedinquiry, kemampuan berpikir kritis dan kreativitas siswa terhadap prestasi belajar kognitif, afektif, dan psikomotor.

Berdasar data hasil penelitian siswa dengankemampuan berpikir kritis tinggi kreativitas tinggi pada pembelajaran $L C$ 7 Ememberikan nilai prestasi yang lebih tinggi dibandingsiswadengan kemampuan berpikir kritis rendah kreativitas rendah. Demikian juga pada pembelajaran guidedinquirysiswa dengankemampuan berpikir kritis tinggi kreativitas tinggi memperoleh nilai prestasi belajar yang lebih tinggi dibanding siswa dengan kemampuan berpikir kritis rendah kreativitas rendah.

Tetapi perolehan nilai prestasi belajar kognitif, afektif, dan psikomotor siswa kelas $L C$ $7 E$ lebih tinggi dibandingkan perolehan nilai kelas guided inquiry pada materi larutan elektrolit dan non elektrolit dibandingkan kelas guided inquiry.

\section{Kesimpulan dan Rekomendasi}

Kesimpulan dari pembahasan diatas adalah sebagai berikut:

1. Ada pengaruh pembelajaran learning cycle $7 E$ (LC 7E) dan guided inquiry terhadap prestasi belajar kognitif tetapi tidak ada pengaruh terhadap prestasi belajar afektif dan 
psikomotor pada materi larutan elektrolit dan non elektrolit siswa kelas X SMAN 1 Magetan tahun pelajaran 2012/2013.

2. Tidak ada pengaruh kemampuan berpikir kritis terhadap prestasi belajar kognitif tetapi ada pengaruh terhadap prestasi belajar afektif dan psikomotor pada materi larutan elektrolit dan non elektrolit siswa kelas X SMAN 1 Magetan tahun pelajaran 2012/2013.

3. Tidak ada pengaruh kreativitas terhadap prestasi belajar kognitif dan afektif tetapi ada pengaruh terhadap prestasi belajar psikomotor pada materi larutan elektrolit dan non elektrolit siswa kelas X SMAN 1 Magetan tahun pelajaran 2012/2013.

4. Tidak ada interaksi antara pembelajaran learning cycle $7 E$ dan guidedinquiry dengan kemampuan berpikir kritis terhadap prestasi belajar kognitif, afektif dan psikomotor siswa pada materi larutan elektrolit dan non elektrolit siswa kelas X SMAN 1 Magetan tahun pelajaran 2012/2013.

5. Tidak ada interaksi antara pembelajaran learning cycle $7 E$ dan guidedinquiry dengan kreativitas terhadap prestasi belajar siswa pada materi larutan elektrolit dan non elektrolit siswa kelas X SMAN 1 Magetan tahun pelajaran 2012/2013.

6. Ada interaksi antara kemampuan berpikir kritis dan kreativitas siswa terhadap prestasi belajar kognitif maupun psikomotor tetapi tidak ada interaksi terhadap prestasi belajar afektif pada materi larutan elektrolit dan non elektrolit siswa kelas X SMAN 1 Magetan tahun pelajaran 2012/2013.

7. Tidak ada interaksi antara pembelajaran learning cycle $7 E$ dan guidedinquiry,kemampuan berpikir kritis dan kreativitas siswa terhadap prestasi belajar siswa pada materi larutan elektrolit dan non elektrolit siswa kelas X SMAN 1 Magetan tahun pelajaran 2012/2013.

Berdasarkan kesimpulan dari penelitian dapat diajukan rekomendasi sebagai berikut:

a. Pembelajaran menggunakan metode learning cycle $7 E(L C 7 E)$ dan guided inquiry dapat diterapkan pada materi larutan elektrolit dan non elektrolit karena dapat mempermudah memahami konsep-konsep yang ada pada materi tersebut.

b. Kemampuan berpikir kritis dan kreativitas siswa merupakan faktor internal yang perlu diperhatikan dalam mempelajari materi kimia larutan elektrolit dan non elektrolit, guru hendaknya memperhatikan hubungan tersebut sehingga dapat digunakan sebagai bahan pertimbangan pengaturan kelompok pada pembelajaran.

c. Prestasi belajar kognitif, afektif, dan psikomotor siswa dapat ditingkatkan dengan metode pembelajaran $L C \quad 7 E$ karena memberikan hasil yang lebih baik dibandingkan dengan pembelajaran guided inquiry khususnya pada materi larutan elektrolit dan non elektrolit.

\section{Daftar Pustaka}

Alec Fisher. (2009). Berpikir Kritis Sebuah Pengantar. Jakarta: Penerbit Erlangga.

Ausubel D. P, Joseph. D. Novak, and Helen Hanesian. (1978). Educational Psychologi. New York: Halt, Renehart and Winston.

BNSP. (2006). Panduan Penyusunan Kurikulum Tingkat Satuan Pendidikan Jenjang Pendidikan Dasar dan Menengah. Jakarta: Depdiknas.

Eggen, P \& Kauchak, D. (1994). Educational Psychology: Classroom Connetions.New York: Merrill.

Ennis, RH. (1985). Goals for A Critical Thinking Curriculum. Developing minds A Resource Book for Teaching Thinking. Virgia Association for supervisions and Curriculum Development (ASCD):54-57.

Muhksin. (2012). Model Pembelajaran Untuk Meningkatkan Kemampuan Berpikir Kritis Siswa. Tesis. Universitas Pendidikan Indonesia. (Unpublished).

Piaget. J. (1971). Psychology and Epistemology. New York: The Viking Press.

Selo Sumarjan. 1983. Kreativitas, Suatu Tinjauan dari sudut Sosiologi. Jakarta: Dian Rakyat.

Supriyadi, Dedi. (1994). Kreativitas, Kebudayaan dan Perkembangan IPTEK. Bandung: Alfabeta.

Sutee Sornsakda, Paitool Suksringarm, Adisak Singseewo. (2009). Effect of Learning environmental Education Using the 7E-cycle Learning with metacognitive Technique and the Teachers hand Book Approaches on Learning Achievement, Integrated Science Process Skills and Critical Thinking of Mathayomsuksa 5 Student with different Learning Achievement. Pakistan $J$ of Social Science.6(5): 297-303.

Trianto. (2007). Mendesain Model Pembelajaran Inovatif. Jakarta: Bumi Aksara.

Utami Munandar. (2009). Pengembangan Kreativitas Anak Berbakat. Jakarta: Rineka Cipta. 
Pembimbing I

Prof. Dr. Ashadi

NIP. 195101021975011001
Pembimbing II

Drs. Sulistyo Saputro, M.Si.,Ph.D.

NIP. 196809041994031001

Telah dinyatakan memenuhi syarat

Pada Tanggal .......Juli 2013

Ketua Program Studi Pendidikan Sains

Program Pascasarjana UNS

Dr. M. Masykuri, M.Si.

NIP.196811241994031001
Sekretaris Program Studi Pendidikan Sains Program Pascasarjana UNS

Dr. Sarwanto, M.Si.

NIP. 196909011994031002 
